\title{
Validity of narrow-band imaging (NBI) nasoendoscopy on nasopharyngeal carcinoma post therapy biopsy
}

\author{
Veby Novri Yendri ${ }^{* 1,2}$, Camelia Herdini ${ }^{1}$, Bambang Heriwiyanto ${ }^{1}$ \\ ${ }^{1}$ Department of Otorhinolaryngology, Head and Neck Surgery, Faculty of Medicine, Public \\ Health and Nursing, Universitas Gadjah Mada/Dr. Sardjito General Hospital, Yogyakarta, \\ ${ }^{2}$ Department of Otorhinolaryngology, Head and Neck Surgery, Faculty of Medicine, \\ Universitas Islam Indonesia
}

DOI:http://dx.doi.org/10.19106/JMedScie/005004201812

\section{ABSTRACT}

Nasopharyngeal carcinoma (NPC) is the most common malignancy found in the head and neck. It is a unique head and neck cancer due to its radiosensitivity. Therefore, radiotherapy becomes the main modality of therapy. Post-treatment evaluation of NPC is important to assess prognosis. Biopsy that is the gold standard for the evaluation can be performed with a narrow-band imaging (NBI) nasoendoscopy guide. This study aimed to determine the validity of NBI nasoendoscopic examination of NPC post-treatment biopsy. This study was a cross-sectional design for all post-treatment NPC patients who would undergo response assessment at the Department of Otorhinolaryngology, Head and Neck Surgery, Dr. Sardjito General Hospital, Yogyakarta. A total 40 patients during May-June 2018 period who underwent examination sequentially. Biopsy examination was carried out with NBI nasoendoscopy guidance and the results of biopsy were performed histopathological examination. Forty patients showed the results of NBI nasoendoscopic validity on NPC biopsy after treatment included sensitivity $(85.7 \%)$, specificity $(87.8 \%)$, positive predictive value $(60 \%)$, negative predictive value $(96.6 \%)$, positive trend ratio $(7.07)$, negative trend ratio $(0.16)$, and accuracy $(87.5 \%)$. Postoperative $\mathrm{NBI}$ nasoendoscopy features appear homogeneous $(75 \%)$ and inhomogenous $(25 \%)$. In conclusion, NBI nasoendoscopic validity on postoperative NPC biopsy is good.

\section{ABSTRAK}

Karsinoma nasofaring (KNF) merupakan keganasan paling sering di bagian kepala dan leher. Keganasan ini merupakan keganasan yang unik pada bagian kepala dan leher karena radiosensitivitasnya. Oleh Karena itu radioterapi menjadi modalitas terapi yang utama. Evaluasi pasca pengobatan pada KNF penting dilakukan untuk menentukan prognosisnya. Biopi yang merupakan standar emas evaluasi dapat dilakukan dengan petunjuk nasoendoskopi narrow-band imaging (NBI). Penelitian ini bertujuan untuk menentukan validitas pemeriksaan nasoendoskopi NBI dari biopsi pasien KNF pasca pengobatan. Penelitian ini menggunakan rancangan potong lintang untuk semua pasien KNF pasca pengobatan yang akan menjalani penilaian respon di Departemen Otorinolaringologi, Bedah Kepala dan Leher, RSUP Dr. Sardjito, Yogyakarta. Total 40 pasien selama Mei Juni 2018 yang menjalani pemeriksaan secara berurutan. Pemeriksaan biopsy dilakukan sesusi petunjuk nasoendoskopi NBI dan hasil biopsi selanjutnya dilakukan pemeriksaan histopatologi. Empat puluh pasien menunjukkan validitas endoskopi NBI pada biopsy KNF setelah pengobatan yang meliputi sensitivitas $(85,7 \%)$, spesifisitas $(87,8 \%)$, nilai predeksi positif $(60 \%)$, nilai predeksi negative $(96,6 \%)$, rasio kecenderungan positif $(7,07)$, rasio kecenderungan negative $(0,16)$, akurasi $(87,5 \%)$. Gambaran nasoendoskopi NBI setelah operasi kelihatan homogeny (75\%) dan tidak homogeny (25\%). Dapat disimpulkan, validitas nasoendoskopi NBI pada biopsi KNF setelah operasi bagus.

Keywords: validity - nasoendoscopy - narrow-band imaging - post-treatment nasopharyngeal carcinoma 


\section{INTRODUCTION}

Nasopharyngeal carcinoma (NPC) is one of the most common malignancies in ear, nose, throat-head, neck surgery (ENTHNS). It is a squamous cell carcinoma and originates from the nasopharyngeal epithelium in the Rosenmulleri fossa, which is a transitional area. ${ }^{1,2}$ Nasopharyngeal carcinoma contributes $0.7 \%$ of all cancers and ranks at $23^{\text {rd }}$ from all malignancies worldwide. ${ }^{1,3}$ It is a unique head and neck cancer because of its radiosensitivity and it becomes the main modality of therapy that can be combined with chemotherapy in advanced cases. ${ }^{4-7}$

The presence of irregular changes in blood vessel structure in the growth of neoplasms, especially in the nasopharynx, is very useful as a marker to identify the presence of malignancy both early stage and post-treatment residual. Tumors angiogenesis will increase tumor growth, so new blood vessels are usually irregular, brittle and tortuous. ${ }^{8,9}$

Narrow-band imaging (NBI) is an optical technique that can improve diagnostic sensitivity of a nasoendoscopic examination to assess tissue characteristics by using narrow bandwidth filters with absorption peaks in hemoglobin. ${ }^{10}$ The NBI uses 2 light spectrums, which is blue (415 $\mathrm{nm}$ ) that displays blood vessels in superficial mucosa and appear as a brownish color. Green light rays $(540 \mathrm{~nm})$ will show deeper blood vessels in the sub mucosa and appear as bluish color. Therefore, NBI can display vascular patterns or intraepithelial papillary capillary loops (IPCL). ${ }^{11-13}$

The importance of post-treatment NPC evaluation to find out the results of complete or partial therapy. As well as changes in the condition of the nasopharyngeal mucosa due to exposure to chemoradiation, good visualization is needed when biopsy is performed at the right location as a diagnostic standard. This study aimed to determine the validity of NBI nasoendoscopic examination of nasopharyngeal carcinoma post-treatment biopsy.

\section{MATERIALS AND METHODS}

\section{Subjects}

This study was a screening test with a cross sectional study design. All research variable observations were done once in the same episode. Subjects were all NPC patients after chemoradiotherapy who would be evaluated for therapeutic response in Department of Otorhinolaryngology, Head and Neck Surgery, Faculty of Medicine, Public Health and Nursing, Universitas Gadjah Mada/Dr. Sardjito General Hospital, Yogyakarta during May to June 2018.

\section{Protocol of study}

The inclusion criteria of this study were NPC patients 12 weeks after chemoradiotherapy, aged over 17 years old, willing to do nasopharyngeal biopsy, and willing to fill out and sign informed consent. The exclusion criteria were patients with nasopharyngeal secretions that filled the biopsy area, a mass that filled the choana and nasal cavity. The protocol of study has received approval from the Medicine and Health Research Ethics Committee, Faculty of Medicine, Public Health and Nursing, Universitas Gadjah Mada, Yogyakarta.

\section{Statistical analysis}

Data were presented as mean \pm standard deviation (SD) or frequency or percentage. Sensitivity, specificity, positive predictive value, negative predictive value, accuracy, positive likelihood ratio, and negative likelihood ratio of NPC biopsy results using nasoendoscopy NBI were estimated. Moreover, receiver operating characteristic (ROC) curve was constructed and areas under the curve (AUC) were calculated to assess the diagnostic accuracy of the NBI.

\section{RESULTS}

The subjects who met the inclusion and exclusion criteria were 40 samples taken from 20 post-treatment NPC patients who would be conducted response 
assessment, which was 12 weeks after the last chemoradiotherapy. The characteristics of subjects are presented in TABLE 1 . The average age of NPC patients was $52.7 \pm 9.7$ years with a minimum age of 35 years old and a maximum of 65 years old. The higher age range was more than 50 years old (12 cases $/ 60 \%$ ), while the age range of $30-40$ years old and 41-50 years old showed the same number of cases, each of 4 cases $(20 \%)$.

TABLE 1. Characteristics of subjects $(n=20)$

\begin{tabular}{ll}
\hline \multicolumn{1}{c}{ Variable } & \multicolumn{1}{c}{ Value } \\
\hline Age (mean \pm SD years) & $52.7 \pm 9.7$ \\
• Minimum (years) & 35 \\
• Maximum (years) & 65 \\
Age range [n (\%) years] & \\
• 30-40 & $4(20)$ \\
- 41-50 & $4(20)$ \\
• >50 & $12(60)$ \\
Gender [n (\%)] & \\
- Male & $14(70)$ \\
- Female & $6(30)$ \\
Stadium [n (\%)] & \\
- Early (I \& II) & $2(10)$ \\
- Advanced (III \& IV) & $18(90)$ \\
Conventional Nasendoscopy [n & \\
(\%)] & \\
• No mass & $34(85)$ \\
- Suspect mass & $6(15)$ \\
\hline
\end{tabular}

Among 40 NPC samples after chemoradiotherapy there were $7(17.5 \%)$ samples with positive biopsy results which showed that there were still NPC mass residuals (TABLE 2). Six of the 7 samples showed the results of NBI examination with suspected residual, and 1 of 7 gave a false negative NBI picture. The number of samples that showed negative biopsy results which means a complete therapeutic response and nasopharyngeal area were cancer-free in a number of $33(82.5 \%)$ samples, including giving a negative NBI picture of $29(72.5 \%)$ samples and 4 of 33 samples showing NBI false positives.

The assessment of the sensitivity of NBI examination in post-treatment NPC was $85.7 \%$, this indicates the ability of NBI to be good enough in detecting the possibility of a NPC mass residual which also showed positive value from biopsy. The value of NBI examination specificity for estimating the absence of NPC mass residual after treatment was $87.8 \%$, this showed the ability of the NBI to exclude the possibility of false negatives that are quite good.

The positive predictive value in this study was $60 \%$ which showed the probability of patients with positive NBI images giving positive biopsy results. This value was not very good due to the bias of thickening of the nasopharyngeal mucosa due to the effects of radiation or a residual mass of cancer. The negative predictive value in this study was good, about $96.6 \%$ so that the NBI examination can be relied upon to detect the possibility of clean therapeutic results (TABLE 2). 
TABLE 2. Sensitivity, specificity, positive predictive value, negative predictive value, positive likelihood ratio, and negative likelihood ratio of NPC biopsy results using nasoendoscopy NBI

\begin{tabular}{lcccc}
\hline & \multicolumn{2}{c}{$\begin{array}{c}\text { Nasopharyngeal } \\
\text { biopsy }\end{array}$} & Total \\
\cline { 1 - 3 } Nasoendoscopy & + & $6(15 \%)$ & $4(10 \%)$ & \\
NBI & $(\mathrm{a})$ & $(\mathrm{b})$ & & $(\mathrm{a}+\mathrm{b})$ \\
& & $1(2.5 \%)$ & $29(72.5 \%)$ & $30(75 \%)$ \\
\multirow{2}{*}{ Total } & $(\mathrm{c})$ & $(\mathrm{d})$ & $(\mathrm{c}+\mathrm{d})$ \\
& & $7(17.5 \%)$ & $33(82.5 \%)$ & $40(100 \%)$ \\
\cline { 1 - 2 } & & $(\mathrm{a}+\mathrm{c})$ & $(\mathrm{b}+\mathrm{d})$ & $(\mathrm{a}+\mathrm{b}+\mathrm{c}+\mathrm{d})$ \\
\hline
\end{tabular}

Sensitivity $=\mathrm{a} /(\mathrm{a}+\mathrm{c})=85.7 \%$; Spesifisity $=\mathrm{d} /(\mathrm{d}+\mathrm{b})=87.8 \%$; Positive predictive value $=\mathrm{a} /(\mathrm{a}+\mathrm{b})=60 \%$; Negative predictive value $=\mathrm{d} /(\mathrm{c}+\mathrm{d})=96,6 \%$; Accuracy $=\mathrm{a}+\mathrm{d} /(\mathrm{a}$ $+\mathrm{b}+\mathrm{c}+\mathrm{d})=87.5 \%$; positive likelihood ratio $(\mathrm{LR}+)=$ sensitivity/(1-spesifity): 7.07; negative likelihood ratio (LR-) $=(1$-sensitivity)/spesifity: 0.16

The result of $\mathrm{LR}+$ of 7.07 indicate a positive NBI probability in the sample that was suspected to have residual with a positive NBI probability in a clean sample. The result of LR- was 0.16 which showed a negative probability ratio of NBI results in a sample that still had a residual with a probability of negative NBI results on a clean sample. These results from each LR+ and LR- can be categorized as good.

Based on the sensitivity and specificity results, it can be displayed in the receiver operating characteristic (ROC) curve (FIGURE 1) with the area under the curve (AUC) value of $87.5 \%$ which showed the NBI validity of after treatment NPC biopsy was included in good category.

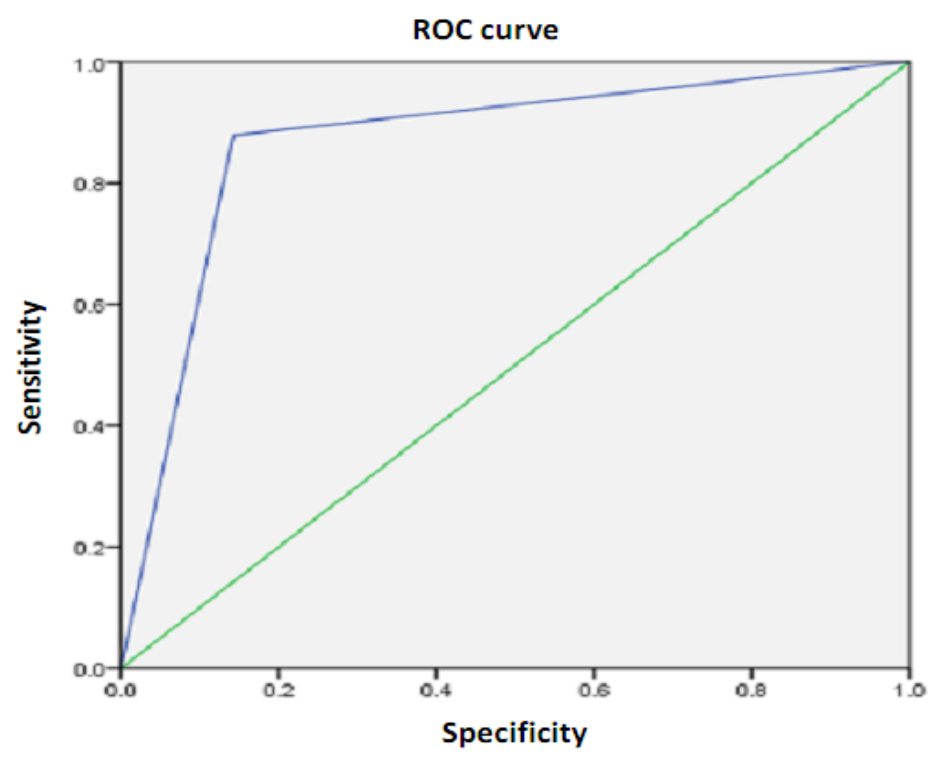

FIGURE 1. Receiver operating characteristic (ROC) curve 


\section{DISCUSSION}

The number of male subjects (14 cases or $70 \%$ ) were higher than female subjects (6 cases or $30 \%$ ) in this study. It was reported that the incidence of NPC in the United States was 1-2 cases per 100,000 males and 0.4 cases per 100,000 females. The comparison of male and female NPC patients was $3: 1$. The incidence of NPC in Indonesia also shows a tendency to occur more often in men than women with a ratio of $2: 1 .{ }^{14}$ In this study, NPC is more common in men compared to women with a ratio of $2.3: 1$. There is still uncertainty of factors that affect NPC more tendency in men. However, it is suspected that there are links between the NPC incidence with genetic factors, life habits, work, and other factors.

Initial signs and symptoms of NPC are not typical and non-specific. The nasopharynx is a difficult area, so NPC is often diagnosed in an advanced stage compared to other malignancies. Because it is rich in lymphatic supply, cervical metastases are often seen in the initial appearance. It was reported that among 122 NPC patients visited in the hospital, first arrived with regional neck metastasis of $54 \%$ cases. ${ }^{1,15}$ This study found 18 cases $(90 \%)$ of patients with advanced NPC, and only 2 cases $(10 \%)$ with stage I and II. In addition, from all of them showed symptoms of neck mass as many as 15 cases $(75 \%)$. Therefore, most of the cases in this study received chemoradiotherapy treatment.

One effect of radiation on a malignancy is the occurrence of a diffuse inflammatory reaction in the area of radiation and its surroundings. This one gives an unsure picture of a bias residual mass. ${ }^{16}$ In this study, from conventional nasoendoscopic examination on both sides of the nasopharynx found that there was still residual mass after therapy in 6 cases $(15 \%)$, while $85 \%$ of the nasopharynx had no mass, slippery surface, limfoephitelial picture disappears.

Narrow-band imaging is an optical technique that is able to increase the diagnostic sensitivity of nasoendoscopic examination to assess tissue characteristics by using narrow bandwith filter in tissue that contain blood vessels. The description of NBI will improve the characteristics of the mucosa that examined, differentiation, and diagnostics. ${ }^{11,12,17}$

Several studies showed that the macroscopic picture of the nasopharyngeal wall does not reflect the presence of residual or NPC especially in post-radiotherapy patients, because the post-radiation nasopharyngeal mucosa becomes fibrosis, nasopharyngitis, and osteoradionecrosis. However, $30 \%$ of NPC cases are recurrent without any tumor appearance seen on endoscopy but histological examination revealed malignancy. ${ }^{17}$

The results of this study can complement previous studies that have reported NBI nasoendoscopic or NPC screening. Piazza et al. ${ }^{18}$ and Lukes et al. ${ }^{19}$ reported that NBI technique had a sensitivity of $91.3-100 \%$ and specificity of $91.6-98 \%$. Furthermore, it would increase when combined using a television screen with an enlargement capability and good quality resolution. A retrospective study reported that NBI was superior in detecting lesions, with a sensitivity and specificity of $92.7 \%$ and 94.5\% compared to conventional endoscopic, about $95.1 \%$ and $63 \% .^{19}$

There is a difference in the appearance of NBI in NPC after therapy due to lysis and death of cancer cells due to exposure to chemoradiotherapy. The appearance of NPC that experienced recurrence appeared as well-defined brownish spots and in inhomogen size. ${ }^{17}$ This study showed 30 samples $(75 \%)$ that gave NBI picture in the form of homogeneous and regular brown spots, and 10 samples (25\%) showed an inhomogenous picture.

There were limitations in this study, including the absence of comparison between nasoendoscopy NBI and conventional so that there is a difference between the two, due to ethical considerations and techniques of action taken at the polyclinic under local anesthesia. 


\section{CONCLUSION}

Validity of NBI nasoendoscopy on posttreatment nasopharyngeal cancer biopsy is good. The NBI can improve the accuracy of nasopharyngeal biopsy in NPC post therapy.

\section{REFERENCES}

1. Wei WI \& Chua DTT. Nasopharyngeal carcinoma. In: Eibling DE \& Newlands SD, editors. Bailey's head and neck surgery otoloaryngology, 5th ed. Philadelphia: Lippincott Williams \& Wilkins, 2014.

2. Jejayakumar A, Brickman TM, Jejayakumar A, Doerr T. Review of nasopharyngeal carcinoma. Ear, Nose Throat J, 2006; 83(3): 168-73.

3. Ma J, Cao S. The epidemiology of nasopharyngeal carcinoma. In: $\mathrm{Lu}$ JJ, Cooper JS, Lee AWM, editors. Nasopharyngeal cancer multidisciplinary management. Heidelberg: Springer, 2010. http://dx.doi.org/10.1007/978-3-540-92810-2 _ 1

4. Tan EH, Soh LT, Ang PT. Chemotherapy of NPC. In: Nasopharyngeal carcinoma. Chong VFH \& Tsao SY editors. Singapore: Loi Printing Pte Ltd, 1997.

5. Prssad U, Wahid MIA, Jalaludin MA, Abdullah BJJ, Paramsothy M, AbdulKareem S. Long-term survival of nasoparyngeal carcinoma patients treated with adjuvant chemotherapy subsequent to conventional radical radiotherapy. Int J Radiat Oncol Bio Phys 2002; 53:648-55. http://dx.doi.org/10.1016/S0360-3016(02)02765-7

6. Kentjono WA. Perkembangan terkini penatalaksanaan karsinoma nasofaring. MajalahKedokteran TropisIndonesia,2003 14(2): 1-39.

7. Suwito S. Radioterapi pada tumor ganas kepala dan leher (squamous cell ca). Dalam: Pendidikan Kedokteran Berkelanjutan III Ilmu Penyakit Telinga Hidung tenggorok-Kepala Leher. Surabaya: SMF Ilmu Penyakit THT-KL FK Unair/ RSUD Dr. Soetomo, 2002.

8. Plank MJ \& Sleeman BD. Tumourinduced angiogenesis: A review. J Theor
Med 2003; 5:137-53.

http://dx.doi.org/10.1080/10273360410001700843

9. Nishida N, Yano H, Nishida T, Kamura T, Kojiro M. Angiogenesis in cancer. Vasc Health Risk Manag 2006; 2(3):213-9.

ht tp://dx.doi.org/10.2147/ vhrm.2006.2.3.213

10. 10. Lin YC, Wang WH. Narrow-band imaging for getecting early recurrent nasopharyngeal carcinoma. Head Neck 2009; 33(4):591-4. http://dx.doi.org/10.1002/hed.21310.

11. Adham M, Kurniawan AN, Muhtadi AI, Roezin A, Hermani B, Gondhowiarjo $\mathrm{S}$, et al. Nasopharyngeal carcinoma in Indonesia: epidemiology, incidence, signs, and symptoms at presentation. Chin J Cancer 2012; 31(4):185-96. http://dx.doi.org/10.5732/cjc.011.10328.

12. Muto M, Nakane M, Katada C, Sano Y, Ohtsu A, Esumi H, et al. Squamous cell carcinoma in situ at oropharyngeal and hypopharyngeal mucosal sites. Cancer 2004; 101:1375-81. http://dx.doi.org/10.1002/cncr.20482

13. Piazza C, Dessouky O, Peretti G, Cocco D, De Benedetto L, Nicolai P. Narrowband imaging: a new tool for evaluation of head and neck squamous cell carcinomas. Review of literature. Acta Otorhinolaryngol Ital 2008; 28(2):49-54

14. Fachiroh J, Prasetyanti PR, Paramita DK, Prasetyawati AT, Anggrahini DW, Haryana SM, et al. Dried-blood sampling for epstein-barr virus immunoglobulin $\mathrm{G}$ (IgG) and IgA serology in nasopharyngeal carcinoma screening. J Clin Microbiol 2008; 246(4):1374-80. http://dx.doi.org/10.1128/JCM.01368-07

15. Fisher D, Knobf TM, Durivage HJ. Head and neck squamous cell carcinoma. In: Fischer DS, Durivge HJ, Knobf MT, Beaulieu N editors. The cancer chemotherapy handbook. 5th ed. St Louis Baltimore Boston: Mosby, 1997.

16. Priyanto \& Herdini C. Peran narrow band-imaging pada karsinoma nasofaring. Jurnal Kesehatan Andalas 2015; 4(1): 326-37

17. Wang WH, Lin YC, Lee KF, Weng HH. 
Nasopharyngeal carcinoma detected by narrow-band imaging endoscopy. Oral Oncol 2011; 47:736-41.

http://x.doi.org/10.1016/j.oraloncology.2011.02.012

18. Piazza C, Cocco D, Del Bon F, Mangili S, Nicolai P, Peretti G. Narrow band imaging and high definition television in the endoscopic evaluation of upper aero-digestive tract cancer. Acta Otorhinolaryngol Ita 2011; 31:70-75.

19. Lukes P, Zabrodsky M, Plazk J, Chovanec M, Betka J, Foltynova E, et al. Narrow band imaging (NBI) - endoscopic method for detection of head and neck cancer. Endoscopy 2013; 75-87. http://dx.doi.org/10.5772/52738 